\title{
New Zinc Coordination Compound with Simple Salicylato and Pyridine Ligands: Synthesis, Crystal Structure and Hirshfeld Surface Analysis
}

\author{
Nives Kitanovski and Marta Počkaj \\ Faculty of Chemistry and Chemical Technology, University of Ljubljana, Večna pot 113, SI-1000 Ljubljana, Slovenia. \\ *Corresponding author: E-mail: marta.pockaj@fkkt.uni-lj.si
}

Received: $12-08-2020$

\begin{abstract}
A novel mononuclear zinc coordination compound with formula $\left[\mathrm{Zn}(\mathrm{Hsal})_{2}(\mathrm{Py})_{2}\right]\left(\mathrm{H}_{2}\right.$ sal = salicylic acid, $\mathrm{Py}=$ pyridine $)$ was prepared by mixing aqueous solutions of sodium salicylate and zinc sulfate in 1:1 molar ratio, and to the resulting solution pyridine was added dropwise. The obtained compound was characterized by elemental analysis, IR spectroscopy, and its crystal structure was determined by single-crystal X-ray diffraction method. X-ray structure analysis has shown that the central zinc ion is four-coordinated by two monodentate salicylato ligands and two pyridine molecules, forming a distorted tetrahedron. Since the asymmetric unit consists of two halves of coordination molecules, orthorhombic Ibca space group symmetry leads to two coordination molecules with slightly different geometry. The comparison between the two is given in terms of interatomic distances and angles, and also in terms of differences in intermolecular interactions obtained as a result of Hirshfeld surface analysis. With the assistance of $\mathrm{C}-\mathrm{H} \cdots \mathrm{O}$ interactions, the adjacent molecules are linked into chains and further connected into three-dimensional network.
\end{abstract}

Keywords: Coordination chemistry; zinc; salicylic acid; crystal structure; Hirshfeld surface analysis.

\section{Introduction}

Although zinc is deemed to be a trace element in the human body, it is present in all organs, tissues and fluids, in total 2-4 grams. Its importance for the growth and existence of all living organisms has been known for more than hundred years. ${ }^{1}$ The research on zinc coordination chemistry has been initiated in the early 1940 s by the discovery of erythrocyte carbonic anhydrase which is involved in the transport of carbon dioxide in blood. Apart from being a part of enzymatic active sites of all six different enzyme classes with catalytic and regulatory functions (oxidoreductases, transferases, hydrolases, lyases, isomerases, and ligases), zinc also plays structural roles and as such contributes to the stability of proteins. With its $d^{10}$ electron configuration, zinc is not subject to reduction or oxidation reactions. Furthermore, its crystal-field stabilization energy is zero, resulting in a remarkably adoptable coordination sphere which allows to accommodate a broad range of coordination numbers and geometries. ${ }^{2}$ All of listed characteristics of zinc as a central ion in combination with various ligands lead to new compounds with interesting antimicrobial, antidiabetic, optical, magnetic and other physical properties. ${ }^{3-10}$
On the other hand, salicylic acid $\left(\mathrm{H}_{2}\right.$ sal; Fig. 1) has been found in numerous plant species where it acts as a phytohormone necessary for plant growth and development. Its salts and esters, salicylates, are widely used in medicine. With their two functional groups, i.e. hydroxylic and carboxylic, salicylates are of great importance as ligands in coordination chemistry with their versatile coordination modes. ${ }^{11}$ For example, zinc acetylsalicylate with formula $\left[\mathrm{Zn}(\mathrm{acsal})_{2}\left(\mathrm{H}_{2} \mathrm{O}\right)_{2}\right]$ is used as anti-inflammatory agent. ${ }^{12}$

Despite the numerous researches in zinc chemistry, there are not as many reports on crystal structures containing the unsubstituted salicylato ligand and additional pyridine-like ligands as one might expect. ${ }^{13}$ Only four<smiles>O=C(O)c1ccccc1O</smiles>

Figure 1. Salicylic acid. 
such crystal structures were reported till now ${ }^{14-17}$ which might indicate considerable difficulties with the crystallization of mononuclear coordination compounds of the entitled class. However, we have managed to prepare the new zinc coordination compound with two salicylato and two additional pyridine ligands. In the present work, its synthesis and characterization, including the single crystal structure determination and Hirshfeld surface analysis, is described.

\section{Experimental}

\section{1. Materials and Physical Measurements}

All reagents and chemicals were purchased from commercial sources and used without further purification.

$\mathrm{CHN}$ elemental analyses were performed with a PerkinElmer $2400 \mathrm{CHN}$ Elemental Analyzer. The infrared spectra were measured on solid samples using a Perkin-Elmer Spectrum 100 series FT-IR spectrometer equipped with an ATR sampling accessory.

\subsection{Synthesis}

To the solution of sodium salicylate, $\mathrm{C}_{7} \mathrm{H}_{5} \mathrm{NaO}_{3}$, (178 mg, $1.11 \mathrm{mmol}$ in $2 \mathrm{~mL}$ water) the solution of $\mathrm{ZnSO}_{4}$ (300 mg, $1.04 \mathrm{mmol}$ of $\mathrm{ZnSO}_{4} \cdot 7 \mathrm{H}_{2} \mathrm{O}$ in $5 \mathrm{~mL}$ water) was added. To the obtained colourless solution, pyridine was added dropwise ( 15 droplets, i.e. $\sim 0.7 \mathrm{~mL}$ ). The white solid, hydrated $\mathrm{ZnSO}_{4}$, appeared immediately after the addition of pyridine. The reaction mixture including the fine white solid was left in an open Erlenmeyer flask at ambient temperature. The quantity of white solid decreased with time and after its disappearance, colourless single crystals suitable for the structural analysis grew out of the solution in 18 days. Yield: $50 \mathrm{mg}$ (10\%). Anal. Calcd. for $\mathrm{C}_{24} \mathrm{H}_{20} \mathrm{~N}_{2} \mathrm{O}_{6} \mathrm{Zn}$ : C, $57.90 \%$; H, 4.05\%; N, 5.63\%. Found: C, 56.89\%; H, 4.14\%; N, 6.08\%. $v_{\max }: 3077$ (vw), $1632(\mathrm{w}$, $\mathrm{C}=\mathrm{N}$ from pyridine ring), $1601\left(\mathrm{~s}, \mathrm{v}_{\mathrm{as}}(\mathrm{OCO})\right), 1567(\mathrm{~s})$, 1541 (s), 1487 (s), 1468 (s), 1450 (s), 1394 (vs, v $($ OCO)), 1319 (s), 1239 (s), 1220 (s), $1156(\mathrm{~s}), 1098(\mathrm{w}), 1071(\mathrm{w})$, $1044(\mathrm{~s}), 1015(\mathrm{w}), 957(\mathrm{w}), 885(\mathrm{~s}), 864(\mathrm{~s}), 831(\mathrm{~s}), 755$ (w), 697 (vs), $670(\mathrm{~s}), 638(\mathrm{~s})$.

\section{3. X-Ray Crystallography}

For X-ray structural analysis, single crystal of the title compound was dipped into silicon grease, mounted onto the tip of glass fibres and transferred to the goniometer head in the liquid nitrogen cryostream. Data were collected on a SuperNova diffractometer equipped with Atlas detector using CrysAlis software and monochromated Mo Ka radiation $(0.71073 \AA)$ at $150 \mathrm{~K} .{ }^{18}$ The initial structural model was obtained via direct methods using the Superflip structure solution program. ${ }^{19}$ A full-matrix least-squares refinement on $F^{2}$ magnitudes with anisotropic displace- ment parameters for all nonhydrogen atoms using SHELXL-2018/3 was employed. ${ }^{20}$ All $\mathrm{H}$ atoms were initially located in difference Fourier maps; those residing on $\mathrm{C}$-atoms were further treated as riding on their parent atoms with $\mathrm{C}$ (aromatic) $-\mathrm{H}$ distance of $0.95 \AA$ A . On the other hand, the hydrogens bonded to oxygen atoms (i.e. $\mathrm{H} 3$ and H6) were refined freely. Details on crystal data, data collection and structure refinement are given in Table 1. Figures depicting the structures were prepared with Mercury. ${ }^{21}$

Table 1. Crystal data, data collection and refinement.

\begin{tabular}{ll}
\hline Crystal data & {$\left[\mathbf{Z n}(\mathbf{H s a l})_{2} \mathbf{P y}_{2}\right]$} \\
\hline Formula & $\mathrm{C}_{24} \mathrm{H}_{20} \mathrm{~N}_{2} \mathrm{O}_{6} \mathrm{Zn}$ \\
$M_{\mathrm{r}}$ & 497.79 \\
Cell setting, space group & Orthorhombic, Ibca \\
$a / \AA$ & $15.2247(5)$ \\
$b / \AA$ & $15.5719(6)$ \\
$c / \AA$ & $37.7204(17)$ \\
$V / \AA^{3}$ & $8942.7(6)$ \\
$Z$ & 16 \\
$D_{\mathrm{x}} / \mathrm{Mg} \mathrm{m}^{-3}$ & 1.479 \\
$\mu / \mathrm{mm}^{-1}$ & 1.142 \\
$F(000)$ & 4096 \\
Crystal form, colour & prism, colourless \\
Crystal size / mm ${ }^{3}$ & $0.25 \times 0.15 \times 0.15$
\end{tabular}

\section{Data collection}

T/ K 150(2)

No. of measured, independent $24914,6220,4140$ and observed reflections

$\begin{array}{ll}R_{\text {int }} & 0.0373\end{array}$

\section{Refinement}

$R$ (on $F_{\text {obs }}$ ), wR (on $F_{\text {obs }}$ ), $S \quad 0.0339,0.0801,1.025$

No. of contributing reflections 6220

No. of parameters 307

No. of restraints none

$\Delta \rho_{\max }, \Delta \rho_{\min } / \mathrm{e} \AA^{-3} \quad 0.732,-0.733$

$R=\Sigma|| F_{\mathrm{o}}|-| F_{\mathrm{c}}|| / \Sigma\left|F_{\mathrm{o}}\right| ; w R_{2}=\left\{\Sigma\left[w\left(F_{\mathrm{o}}^{2}-F_{\mathrm{c}}{ }^{2}\right)^{2}\right] / \Sigma\left[w\left(F_{\mathrm{o}}{ }^{2}\right)^{2}\right]\right\}^{1 / 2} ; S=$ $\left\{\Sigma\left[w\left(F_{\mathrm{o}}^{2}-F_{\mathrm{c}}^{2}\right)^{2}\right] /(n-p)\right\}^{1 / 2}$ where $n$ is the number of independent reflections and $p$ is the total number of parameters refined.

\section{4. Hirshfeld Surface Analysis}

The Hirshfeld surface of the molecule is defined as a set of points in three-dimensional space where the contribution to the electron density of the molecule of interest is equal to the contribution from all other molecules. ${ }^{22}$ The Hirshfeld surface analyses were performed and fingerprint plots were drawn using Crystal Explorer, both based on the results of previous single crystal X-ray diffraction study. ${ }^{23}$ The Hirshfeld surfaces were plotted over three quantities: a) $d_{\text {norm }}$, plotted in red-white-blue colour code, representing shorter/close to the sum of van der Waals radii/longer contacts between the molecules; b) shape index; 
the red colour represents concave and the blue convex regions; and c) curvedness. Furthermore, the 2D fingerprint plots, i.e. plots of $d_{\mathrm{i}}$ over $d_{\mathrm{e}}$ are provided to recognize and evaluate different intermolecular contacts in the crystal. $d_{\mathrm{i}}$ and $d_{\mathrm{e}}$ represent distances from the isosurface to the nearest atom inside or outside to the Hirshfeld surface, respectively.

\section{Results and Discussion}

\section{1. Crystal structure}

Single crystal X-ray structure determination has shown that the title compound crystallizes in orthorhombic Ibca space group (no. 73). The asymmetric unit consists of two central zinc ions, each surrounded by a pyridine molecule and a salicylato ligand. The aforementioned space group symmetry leads to two similar but not completely identical coordination molecules with formula $\left[\mathrm{Zn}(\mathrm{Hsal})_{2}(\mathrm{Py})_{2}\right]$ (Fig. 2a), hereinafter referred to molecule1 (containing Zn1) and molecule2 (containing Zn2); their overlay is shown in Fig. $2 \mathrm{~b}$.
Table 2. Selected bond lengths and angles $\left(\AA,^{\circ}\right)$ for $\mathbf{1}$.

\begin{tabular}{lllr}
\hline Molecule1 & & Molecule2 & \\
\hline Zn1-O2 & $1.9502(13)$ & Zn2-O5 & $1.9533(14)$ \\
Zn1-N1 & $2.0256(15)$ & Zn2-N2 & $2.0405(16)$ \\
O2-Zn1-O2 & $134.83(9)$ & O5-Zn2-O5 & $133.95(8)$ \\
N1-Zn1-N1 & $119.61(9)$ & N2-Zn2-N2 & $111.42(9)$ \\
O2-Zn1-N1 & $97.83(6)$ & O5-Zn2-N2 & $105.38(6)$ \\
$\mathrm{O}^{i}-\mathrm{Zn} 1-\mathrm{N} 1$ & $104.48(6)$ & $\mathrm{O}^{i i}-\mathrm{Zn} 2-\mathrm{N} 2$ & $100.11(6)$ \\
\hline
\end{tabular}

Symmetry codes: (i) $x,-y,-z+1 / 2 ;$ (ii) $-x+1 / 2, y,-z$.

gles between the meanplane defined by carboxylate group and the salicylate ring are similar, with values of $7.1(1)^{\circ}$ in molecule1 and $6.4(1)^{\circ}$ in molecule2, respectively. However, the angles between the meanplane of pyridine and salicylate rings differ significantly, with values $50.49(8)^{\circ}$ in molecule1 and $82.21(6)^{\circ}$ in molecule2, respectively. This difference is further reflected in the packing of the coordination molecules and also in slightly different hydrogen bonding schemes / close contacts of both molecules (Table 3). In molecule1 two intramolecular hydrogen bonds of a)

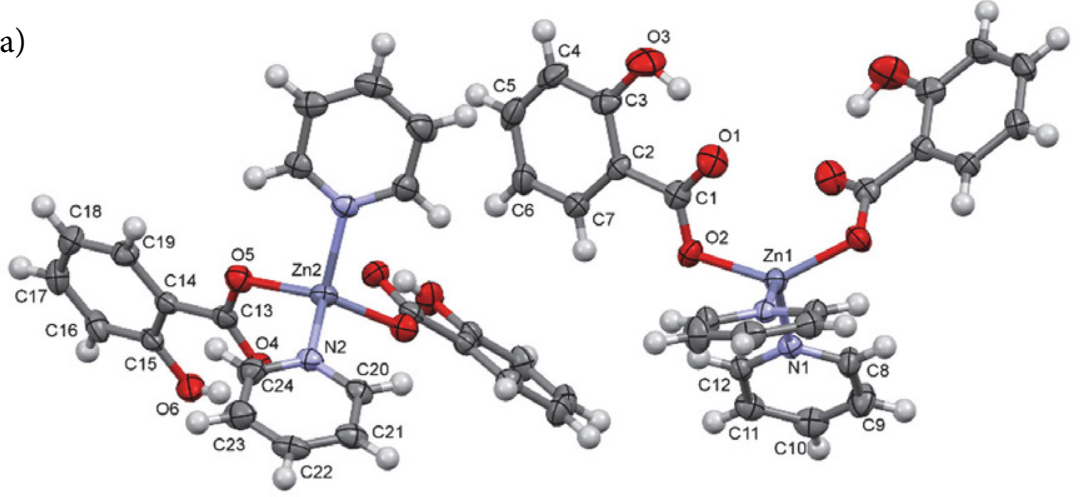

b)

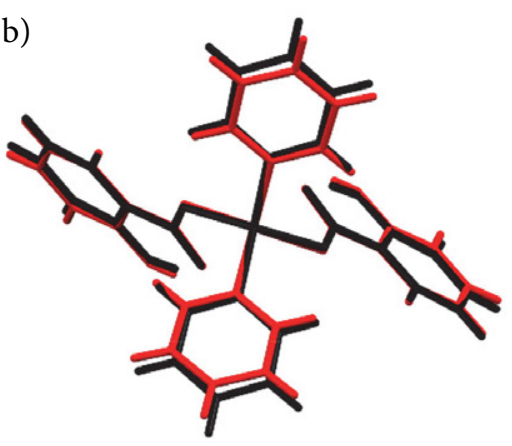

Figure 2. a) Two similar coordination molecules $\left[\mathrm{Zn}(\mathrm{Hsal})_{2}(\mathrm{Py})_{2}\right]$. The displacement ellipsoids of non-hydrogen atoms are drawn at the $50 \%$ probability level while the hydrogen atoms are drawn as spheres of arbitrary radii and their labels are omitted for clarity. b) Overlay of the coordination molecules; molecule1 (i.e. containing $\mathrm{Zn} 1$ ) is black while the molecule2 (containing $\mathrm{Zn} 2$ ) is red.

In both symmetrical coordination molecules, a central $\mathrm{Zn}$ is positioned on a twofold axis running parallel to $x(\mathrm{Zn} 1$, Wyckoff site $8 c)$ or $y$ axis $(\mathrm{Zn} 2$, Wyckoff site $8 d)$, respectively, and is surrounded by two pyridine molecules and two monodentately bound salicylato ligands via its deprotonated carboxylic oxygen. The obtained coordination number is four, and the values of $\tau_{4}$ ' parameter ${ }^{24,25}$ of 0.70 for $\mathrm{Zn} 1$ and 0.74 for $\mathrm{Zn} 2$ confirm the distorted tetrahedra around both central ions. Data on selected bond lengths and angles around the central zinc ions are given in Table 2; values are in accordance with the previously reported $\mathrm{Zn}$ complexes with salicylato ligand and its derivatives. ${ }^{13}$

Although bond lengths and angles are quite similar in both molecules, there are some distinctions between them as already seen from their overlay (Fig. 2b). The an-
$\mathrm{O}-\mathrm{H} \cdots \mathrm{O}$ and $\mathrm{C}-\mathrm{H} \cdots \mathrm{O}$ type are present. On the other hand, if considering the classical criterion for $\mathrm{C}-\mathrm{H}$... O hydrogen bonds, i.e. $\mathrm{C}-\mathrm{H} \cdots \mathrm{O}$ angle $>110^{\circ}$ and $\mathrm{C} \cdots \mathrm{O}$ distance $<$ $3.22 \AA$, in molecule 2 only the intramolecular $\mathrm{O}-\mathrm{H}$... O hydrogen bond appears, while there is no $\mathrm{C}-\mathrm{H}$... O hydrogen bond due to geometric differences in between the molecules. The corresponding distance between the same atoms in molecule2 is significantly larger than the sum of

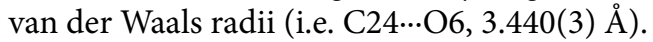

Additional $\mathrm{C}-\mathrm{H} \cdots \mathrm{O}$ contact can be found between two adjacent molecules1 (C11-H11‥O1) or two adjacent molecules2 (C20-H20‥O6), respectively, connecting the molecules with the same numerical label into chains that run parallel to $a$ axis (Fig. 3). The $\mathrm{C}-\mathrm{H} \ldots \mathrm{O}$ hydrogen bonds between molecule1 and molecule 2 are slightly longer than is the sum of van der Waals radii (C5- 
H5...O6) but still connect the aforementioned chains into three-dimensional structure. The difference in hydrogen bonding schemes between both coordination molecules can be also revealed in fingerprint plots of both molecules (see Section 3.2).

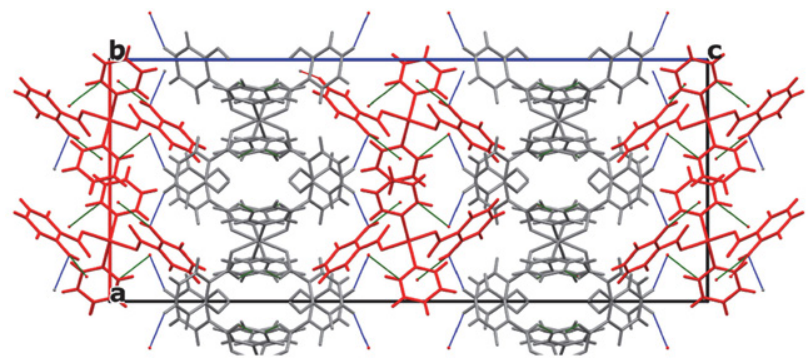

Figure 3. The packing of exchanging chains of hydrogen-bonded molecules1 (grey) and molecules2 (red) that run parallel to $a$ direction. A view down $b$ axis. The hydrogen bonds between molecules 1 or molecules 2 are given in green while those between molecule1 and molecule2 (C5-H5... 6 ) are depicted in blue. the classical crystallographic analysis with which the molecule packing is studied by elucidating atom-to-atom or residue-to residue contacts. Fig. 4a represents Hirshfeld surface of molecule containing $\mathrm{Zn} 1$ (molecule1) mapped over $d_{\text {norm }}$ in a range from -0.179 to +1.501 arbitrary units. The bright red spots ' 1 ' and ' 2 ' in the vicinity of hydrogen (H11) and oxygen (O1) indicate donors and acceptors of $\mathrm{C}-\mathrm{H} \cdots \mathrm{O}$ interaction while the diminutive-red spot ' 3 ' near hydroxylic oxygen (O3) claims its cooperation in a relatively weak $\mathrm{C}-\mathrm{H} \cdots \mathrm{O}$ interaction.

HS mapped over shape index (Fig. 4b) clearly shows red hollows and blue bumps which in a close look from different perspectives can reveal the way the molecules (i. e. their Hirshfeld surfaces) touch each other. Together with HS mapped over curvedness (Fig. 4c), the absence of broad, flat regions can be observed and consequently there is no evidence of planar stacking arrangements of molecules1, e.g. $\pi-\pi$ stacking. ${ }^{26}$

To overcome the trouble of presenting 3D Hirshfeld surfaces in two dimensions, a quantitative $2 \mathrm{D}$ fingerprint

Table 3. Hydrogen bond geometry in $\mathbf{1}$.

\begin{tabular}{llllll}
\hline $\mathbf{D}-\mathbf{H} \cdots \mathbf{A}$ & $\mathbf{D}-\mathbf{H}(\AA)$ & $\mathbf{H} \cdots \mathbf{A}(\AA)$ & $\mathbf{D} \cdots \mathbf{A}(\AA)$ & $\mathbf{D}-\mathbf{H} \cdots \mathbf{A}\left(^{\circ}\right)$ & Symmetry code of A \\
\hline $\mathrm{O} 3-\mathrm{H} 3 \cdots \mathrm{O} 1$ & $0.95(3)$ & $1.67(3)$ & $2.546(2)$ & $151(3)$ & $x, y, z$ \\
$\mathrm{C} 12-\mathrm{H} 12 \cdots \mathrm{O} 2$ & 0.95 & 2.60 & $3.111(2)$ & 114 & $x, y, z$ \\
$\mathrm{C} 11-\mathrm{H} 11 \cdots \mathrm{O} 1$ & 0.95 & 2.46 & $3.203(2)$ & 135 & $-x+1 / 2, y+1 / 2, z$ \\
$\mathrm{O} 6-\mathrm{H} 6 \cdots \mathrm{O} 4$ & $0.84(3)$ & $1.78(3)$ & $2.542(2)$ & $150(3)$ & $x, y, z$ \\
$\mathrm{C} 20-\mathrm{H} 20 \cdots \mathrm{O} 6$ & 0.95 & 2.57 & $3.027(2)$ & 110 & $x, y-1 / 2,-z$ \\
$\mathrm{C} 5-\mathrm{H} 5 \cdots \mathrm{O} 6$ & 0.95 & 2.48 & $3.331(3)$ & 149 & $x-1 / 2,-y+1 / 2,-z$ \\
\hline
\end{tabular}

\subsection{Hirshfeld Surface Analysis}

Hirshfeld surface (HS) analysis is an invaluable tool that enables us to understand and describe weak intermolecular interactions in the crystal structure that are crucial in the packing of molecules in crystals. By means of this method, the molecule is treated as a whole, opposing to plot of molecule1 is presented in Fig. 5. Only the dominant contributions to the Hirshfeld surface, i.e. $\mathrm{H} \cdots \mathrm{H}, \mathrm{C} \cdots \mathrm{H} /$ $\mathrm{H} \cdots \mathrm{C}$ and $\mathrm{O} \cdots \mathrm{H} / \mathrm{H} \cdots \mathrm{O}$ contacts which together contribute more than $92 \%$ to the total HS, are shown. Two symmetrical spikes at $\left(d_{\mathrm{i}}+d_{\mathrm{e}}\right) \sim 2.3 \AA$ represent $\mathrm{C}-\mathrm{H} \cdots \mathrm{O}$ interactions observed as red spots of different intensities in Fig. a)

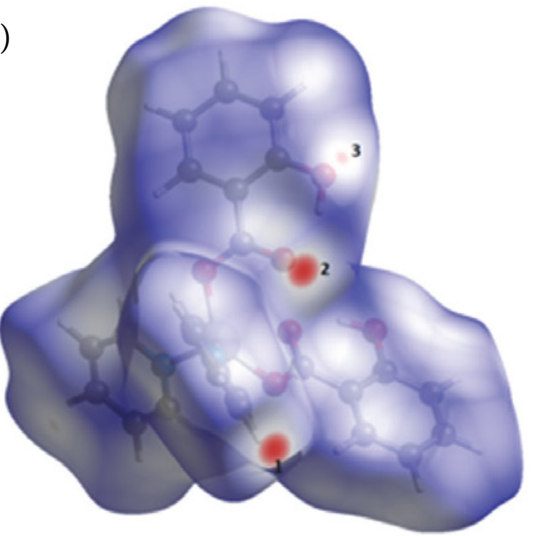

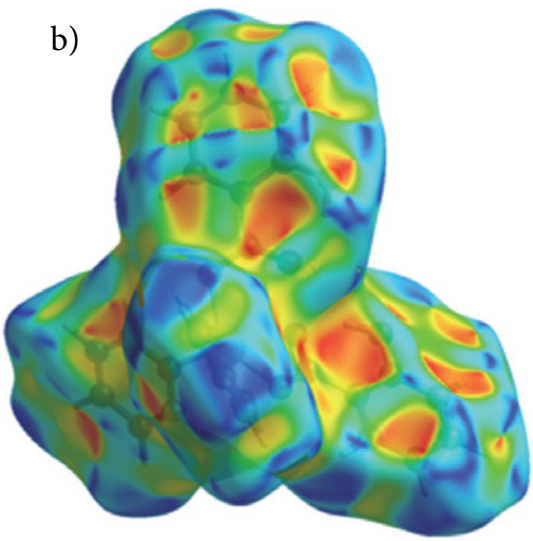

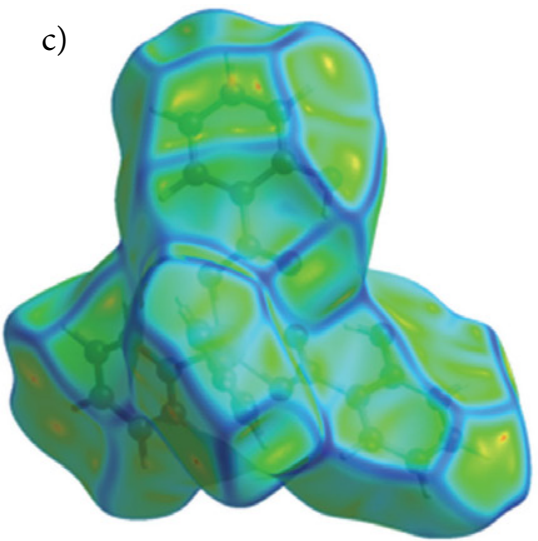

Figure 4. Hirshfeld surface of molecule1 a) plotted over $d_{\text {norm }}$ in the range from -0.179 to +1.501 arbitrary units; b) plotted over shape-index property (range from -1.000 to 1.000 ), and c) plotted over curvedness (range from -4.000 to 0.400 ). 


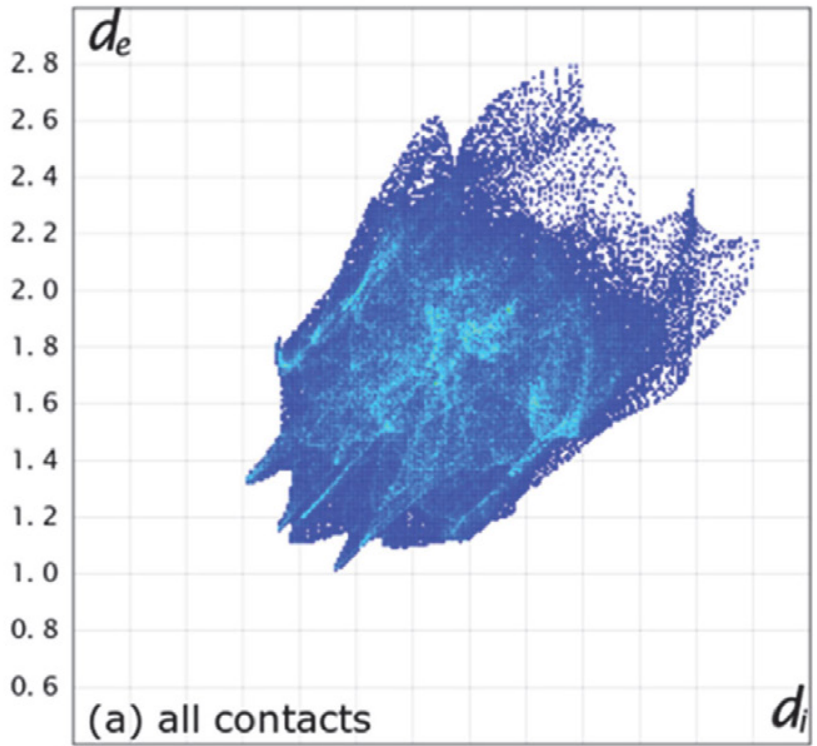

(A) 0.60 .81 .01 .21 .41 .61 .82 .02 .22 .42 .62 .8

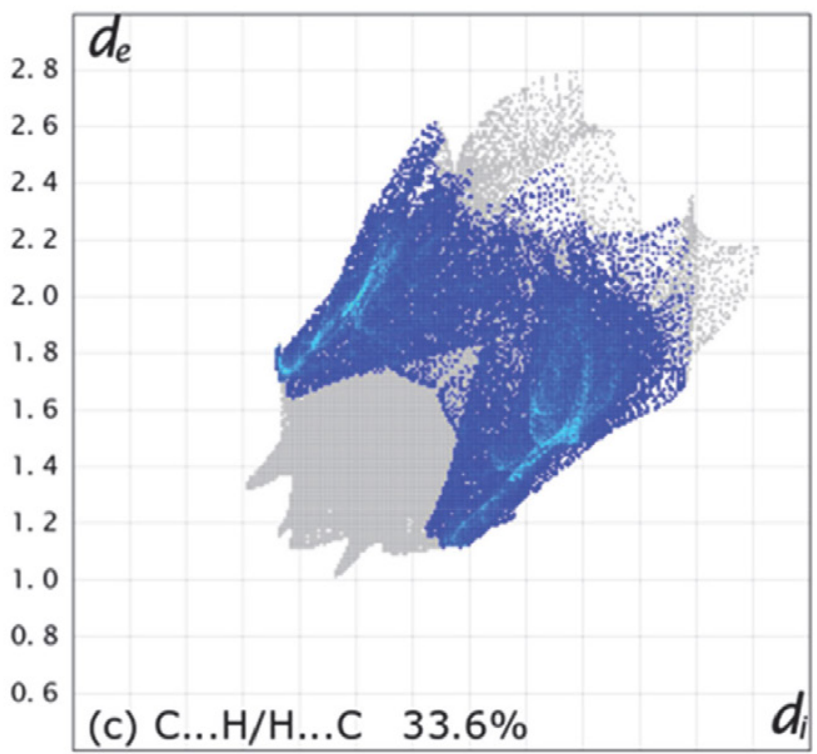

(A) 0.60 .81 .01 .21 .41 .61 .82 .02 .22 .42 .62 .8

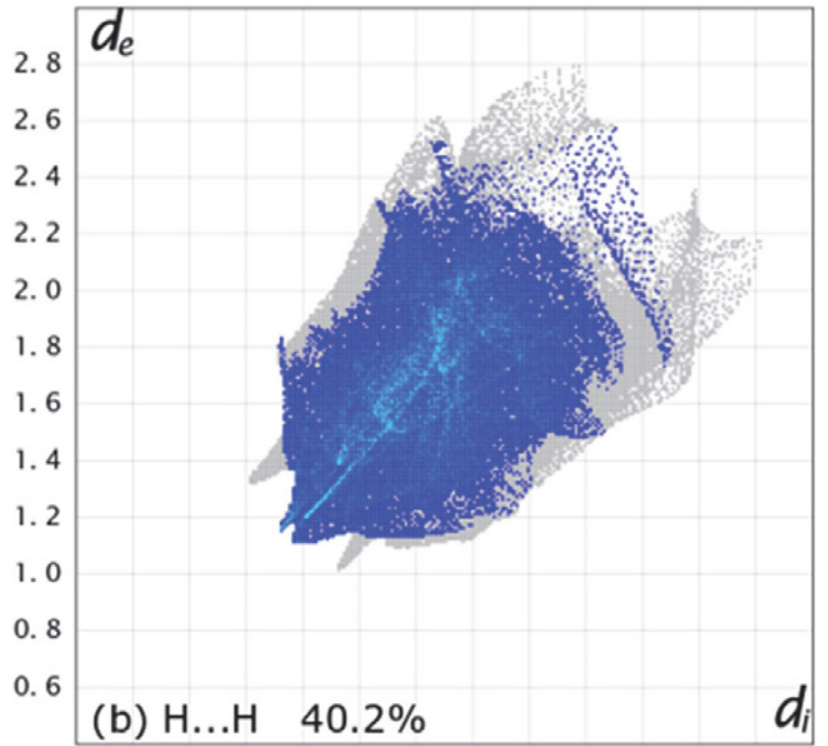

(A) 0.60 .81 .01 .21 .41 .61 .82 .02 .22 .42 .62 .8

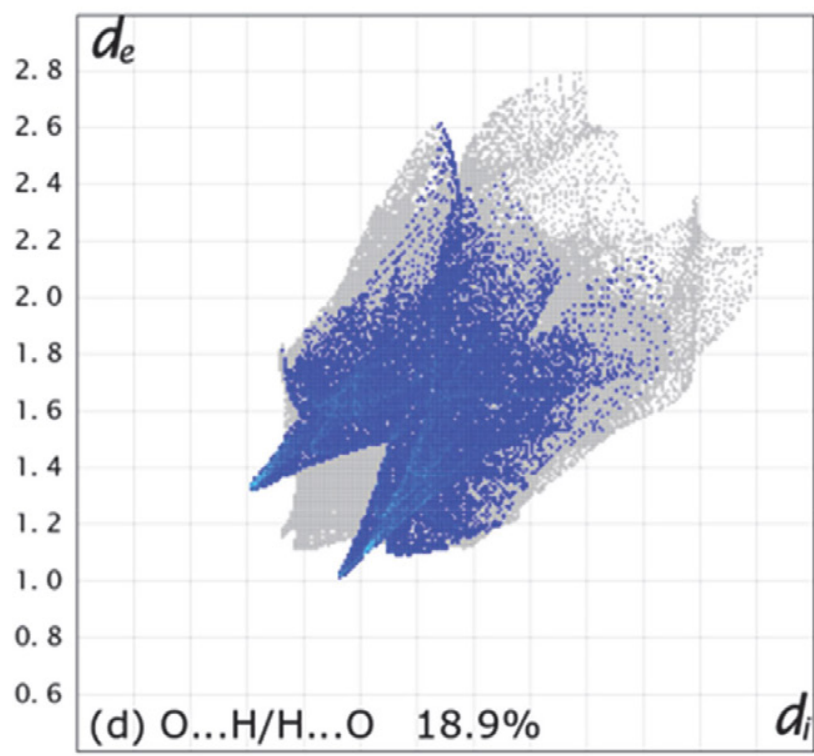

(A) 0.60 .81 .01 .21 .41 .61 .82 .02 .22 .42 .62 .8

Figure 5. a) A full 2D fingerprint plot of molecule1, together with those delineated into b) $\mathrm{H} \cdots \mathrm{H}$, c) $\mathrm{C} \cdots \mathrm{H} / \mathrm{H} \cdots \mathrm{C}$ and d) $\mathrm{O} \cdots \mathrm{H} / \mathrm{H} \cdots \mathrm{O}$ contacts.

4a. All other features that should indicate other important short contacts such as $\pi-\pi$ stacking are absent from $2 \mathrm{D}$ fingerprint plots of molecule1.

Since the asymmetric unit consists of two halves of the coordination molecule and the HS analysis can reveal differences between the two symmetrically independent molecules, it was performed also on the molecule2. The HS mapped over $d_{\text {norm }}$, shape index and curvedness are shown in ESI (Fig. S1). The observations are very similar to those of molecule1. However, slight differences can be observed from 2D fingerprint plots (Fig. 6). The dominant contacts in molecule 2 are the same as in molecule1, and also their contribution to the total HS is similar (>92\%). However, the percentage contributions do differ slightly as a result of subtle geometry differences of both molecules (Fig. 7).

\section{Conclusions}

Crystal structure of a new zinc coordination compound with salicylato and pyridine ligand, i.e. $[\mathrm{Zn}(\mathrm{H}-$ sal $\left.)_{2}(\mathrm{Py})_{2}\right]$ was determined by single-crystal X-ray diffraction at $150 \mathrm{~K}$, and it was further evaluated by Hirshfeld 


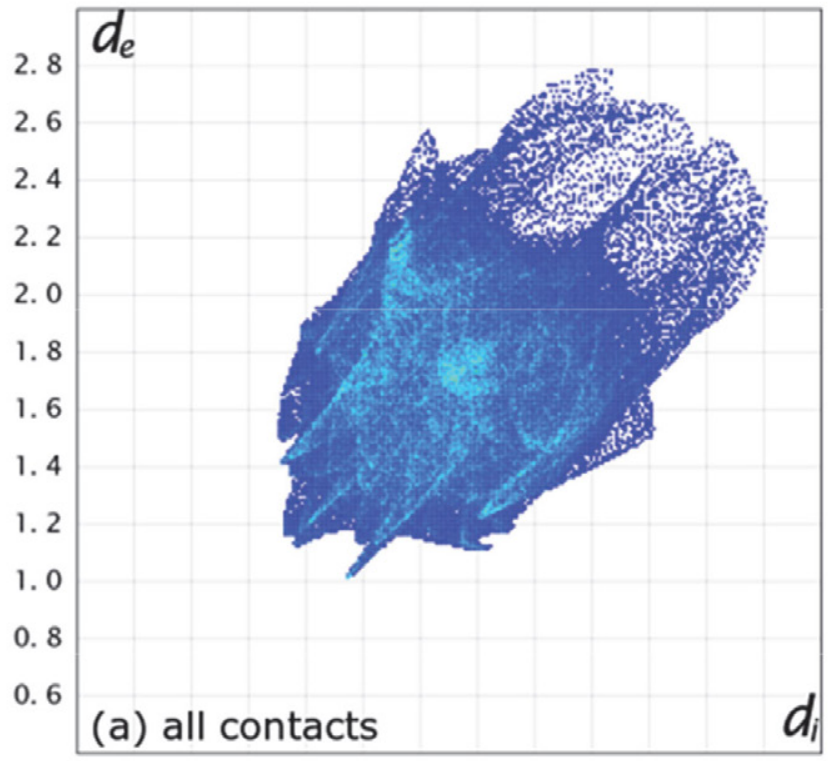

(A) 0.60 .81 .01 .21 .41 .61 .82 .02 .22 .42 .62 .8

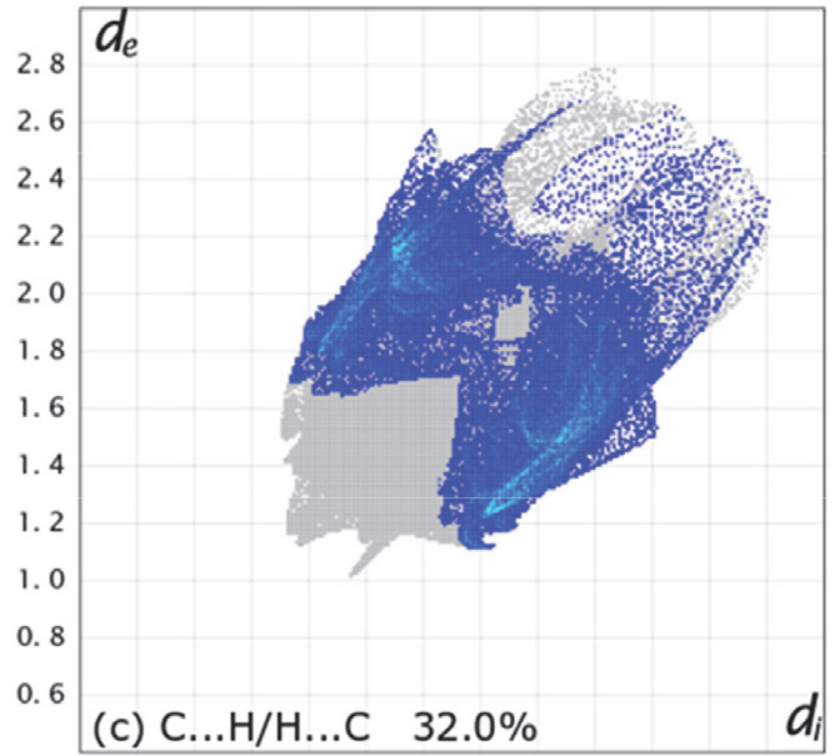

(A) 0.60 .81 .01 .21 .41 .61 .82 .02 .22 .42 .62 .8

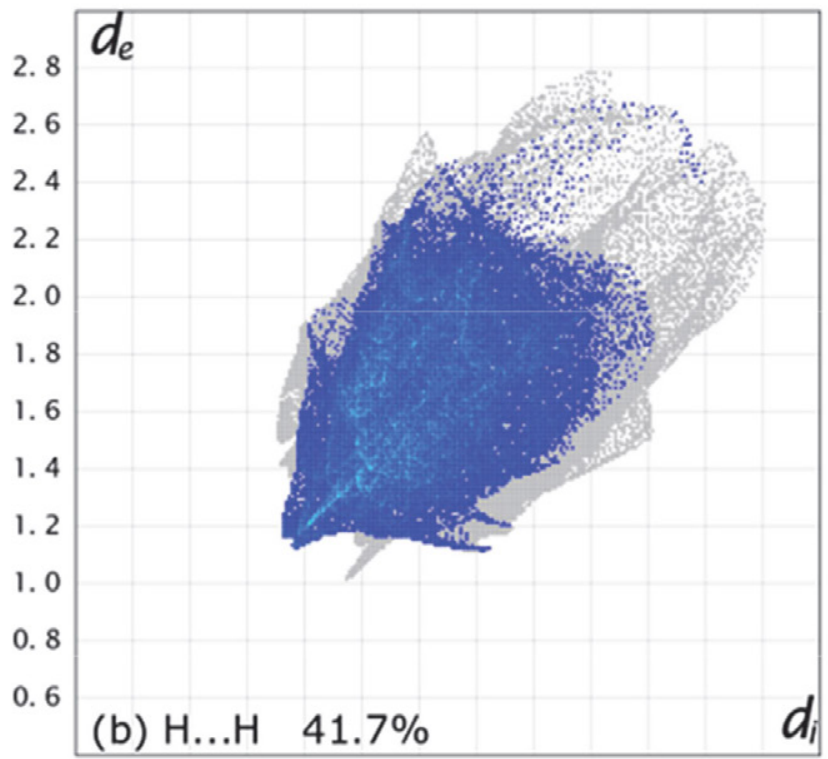

(A) 0.60 .81 .01 .21 .41 .61 .82 .02 .22 .42 .62 .8

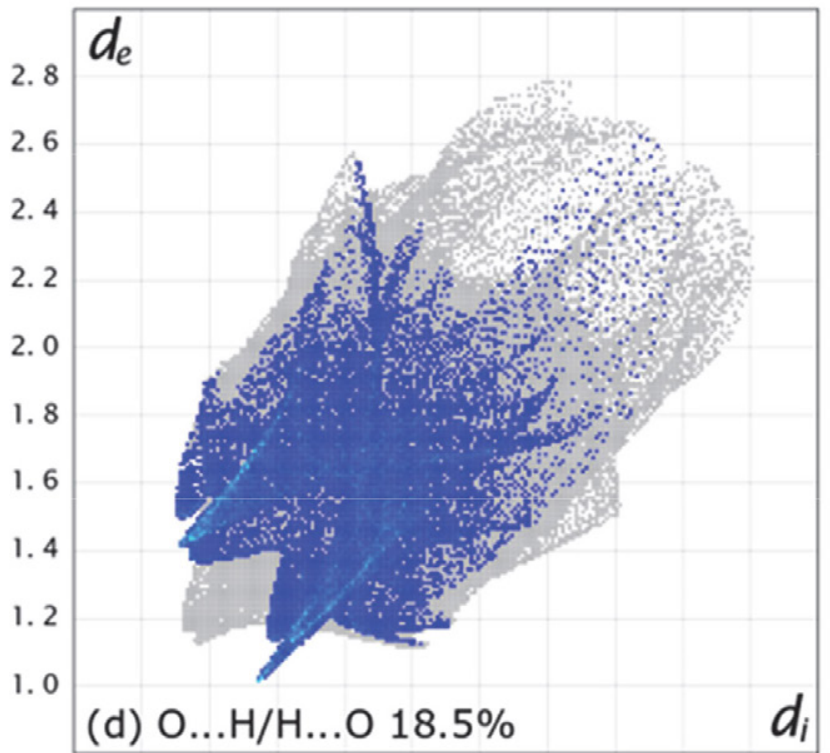

(A) $\quad \begin{array}{llllllllllll}1.0 & 1.2 & 1.4 & 1.6 & 1.8 & 2.0 & 2.2 & 2.4 & 2.6 & 2.8\end{array}$

Figure 6. a) A full $2 \mathrm{D}$ fingerprint plot of molecule 2, together with those delineated into b) $\mathrm{H} \cdots \mathrm{H}, \mathrm{c}$ ) $\mathrm{C} \cdots \mathrm{H} / \mathrm{H} \cdots \mathrm{C}$ and d) $\mathrm{O} \cdots \mathrm{H} / \mathrm{H} \cdots \mathrm{O}$ contacts.

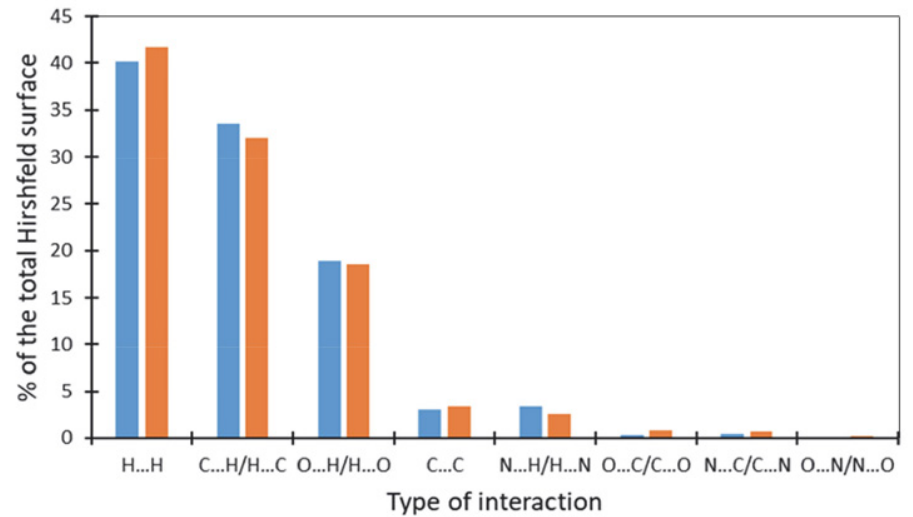

Figure 7. The proportions of different interactions to the total Hirshfeld surface in molecule1 (blue) and molecule2 (orange columns). 
surface analysis. The central $\mathrm{Zn}(\mathrm{II})$ is four-coordinated in a shape of distorted tetrahedron. Since the asymmetric unit consists of two halves of coordination molecule, there are subtle differences between symmetrically independent coordination molecules. In both coordination molecules, $\mathrm{H} \cdots \mathrm{H}, \mathrm{C} \cdots \mathrm{H} / \mathrm{H} \cdots \mathrm{C}$ and $\mathrm{O} \cdots \mathrm{H} / \mathrm{H} \cdots \mathrm{O}$ contacts contribute the most to molecular packing but the percentage of each of the aforementioned interactions to the total Hirshfeld surface differ as a consequence of slight geometrical differences between two coordination molecules. As a result of $\mathrm{C}-$ $\mathrm{H}$... O interactions between the adjacent molecules, the three-dimensional network is formed.

\section{Supplementary Information}

CCDC 2014661 contains the supplementary crystallographic data. These data can be obtained free of charge from The Cambridge Crystallographic Data Centre via www.ccdc.cam.ac.uk/data_request/cif.

\section{Acknowledgments}

This work was financially supported by Slovenian research agency (grant P1-0175). The authors thank Eva Judež for the synthesis and EN-FIST Centre of Excellence for the use of SuperNova diffractometer.

\section{References}

1. M. J. Jackson in: C. F. Mills (Ed.): Zinc in human biology; Springer, London, UK, 1989, pp. 1-10.

2. J. Burgess, R. H. Prince: Zinc: Inorganic \& Coordination Chemistry, in: Encyclopedia of Inorganic Chemistry, 2nd edition, John Wiley \& Sons Ltd., 2006.

3. Y.-L. Sang, X.-S. Lin, W.-D. Sun, Acta Chim. Slov. 2020, 67, 581-585. DOI:10.17344/acsi.2019.5595

4. A. Erxleben, Coord. Chem. Rev. 2003, 246, 203-228. DOI:10.1016/S0010-8545(03)00117-6

5. X.-G. Yi, X.-N. Fang, J. Guo, J. Li, Z.-P. Xie, Acta Chim. Slov. 2020, 67, 507-515. DOI:10.17344/acsi.2019.5532

6. X. Meng, Y. Song, H. Hou, Y. Fan, G. Li, Y. Zhu, Yu Zhu, Inorg. Chem. 2003, 42, 1306-1315. DOI:10.1021/ic0259282

7. D. A. Shultz, S. H. Bodnar, Inorg. Chem. 1999, 38, 591-594. DOI:10.1021/ic981092k

8. T. Koleša-Dobravc, K. Maejima, Y. Yoshikawa, A. Meden, H. Yasui, F. Perdih, New J. Chem. 2018, 42, 3619-3632. DOI:10.1039/C7NJ04189F

9. T. Koleša-Dobravc, K. Maejima, Y. Yoshikawa, A. Meden, H. Yasui, F. Perdih, New J. Chem. 2017, 41, 735-746.

DOI:10.1039/C6NJ02961B

10. N. Podjed, B. Modec, M. M. Alcaide, J. López-Serrano, RSC Adv. 2020, 10, 18200-18221. DOI:10.1039/D0RA03192E

11. K. Praveen, D. S. S. Madhavi, A. Anil Kumar, Y. Kranthi Kumar, Int. J. Eng. Sci. Invention Res. Dev. 2016, 5, 8-10.
12. P. Lemoine, B. Viossat, G. Morgant, F. T. Greenaway, A. Tomas, N.-H. Dung, J. R. J. Sorenson, J. Inorg. Biochem. 2002, 89, 18-28. DOI:10.1016/S0162-0134(01)00324-5

13. C. R. Groom, I. J. Bruno, M. P. Lightfoot, S. C. Ward, Acta Crystallogr. 2016, B72, 171-179.

DOI:10.1107/S2052520616003954

14. H. Necefoglu, W. Clegg, A. J. Scott, Acta Crystallogr. 2001, E57, m462-m464. DOI:10.1107/S1600536801015021

15. T. Hokelek, H. Necefoglu, Anal. Sci. 2001, 17, 1241-1242. DOI:10.2116/analsci.17.1241

16. D. Kose, A. Ay, O. Sahin, O. Buyukgungor, J. Iran. Chem. Soc. 2013, 9, 591-597. DOI:10.1007/s13738-012-0072-9

17. K.-H. Lin, F.-F. Zhang, Z.-Y. Yu, S. Min, Acta Crystallogr. 2007, E63, m1930. DOI:10.1107/S1600536807028322

18. CrysAlisPRO, Oxford Diffraction /Agilent Technologies UK Ltd, Yarnton, England.

19. L. Palatinus, G. Chapuis, J. Appl. Cryst. 2007, 40, 786-790. DOI:10.1107/S0021889807029238

20. G. M. Sheldrick, Acta Crystallogr. 2015, C71, 3-8.

21. C. F. Macrae, P. R. Edgington, P. McCabe, E. Pidcock, G. P. Shields, R. Taylor, M. Towler, J. van de Streek, J. Appl. Crystallogr. 2006, 39, 453-457. DOI:10.1107/S002188980600731X

22. M. J. Turner, J. J. McKinnon, S. K. Wolff, D. J. Grimwood, P. R. Spackman, D. Jayatilaka, M. A. Spackman, CrystalExplorer17. University of Western Australia, 2017. DOI:10.1039/B818330A

23. M. A. Spackman, D. Jayatilaka, CrystEngComm 2009, 11, 19-32.

24. A. Okuniewski, D. Rosiak, J. Chojnacki, B. Becker, Polyhedron 2015, 90, 47-57. DOI:10.1016/j.poly.2015.01.035

25. D. Rosiak, A. Okuniewski, J. Chojnacki, Polyhedron 2018, 146, 35-41. DOI:10.1016/j.poly.2018.02.016

26. S. L. Tan, M. M. Jotani, E. R. T. Tiekink, Acta Crystallogr. 2019, E75, 308-318. DOI:10.1107/S2056989019001129 


\section{Povzetek}

Pri reakciji med vodnima raztopinama natrijevega salicilata in cinkovega sulfata v množinskem razmerju 1:1 in dodatku piridina po kapljicah $\mathrm{v}$ nastalo raztopino je nastala nova enojedrna koordinacijska spojina $\mathrm{s}$ formulo $\left[\mathrm{Zn}(\mathrm{Hsal})_{2}(\mathrm{Py})_{2}\right]\left(\mathrm{H}_{2}\right.$ sal = salicilna kislina, $\mathrm{Py}=$ piridin $)$. Okarakterizirali smo jo s pomočjo elementne analize, infrardeče spektroskopije ter $\mathrm{z}$ rentgensko difrakcijo na monokristalu določili njeno kristalno strukturo. Koordinacijsko število centralnega cinkovega iona je štiri, in sicer je koordiniran s po dvema enoveznima salicilatnima ligandoma ter dvema molekulama piridina, koordinacijski polieder je popačen tetraeder. V asimetrični enoti sta dve polovici koordinacijskih molekul, kot posledica ortorombske prostorske skupine $I b c a$ pa se tvorita dve koordinacijski molekuli z nekoliko različno geometrijo. Podana je primerjava med njima, in sicer tako $v$ smislu medatomskih razdalj in kotov kot tudi v opažanju razlik v medmolekulskih interakcijah, dobljenih s pomočjo analize Hirshfeldovih površin. S pomočjo $\mathrm{C}-\mathrm{H} \cdots \mathrm{O}$ interakcij so sosednje molekule povezane v verige, te pa še naprej tako, da se tvori tridimenzionalna struktura. 